\title{
EMPIRICAL FACTS OF EDUCATIONAL CHANCES FOR WOMEN IN ISLAMIC WORLD: PAST AND PRESENT
}

\author{
HANDOKO JA'FAR ${ }^{1}$, TAUFIK RIGO ${ }^{2}$ \\ ${ }^{1}$ STAI Ma'had Aly Al-Hikam Malang \\ ${ }^{2}$ Ministry of Foreign Affairs, India
}

\begin{abstract}
This article explores educational opportunities in the early period of Islam until the $13^{\text {th }}$ century, which shows the significant role of women in education. It can be argued that the role of women in education can be traced not only in certain areas of religious knowledge but also in the patronage of education and even in determining the political policy of the government. Unfortunately, compared to the next period until the $21^{\text {st }}$ century, policy concerning education has recently turned to unfair treatment such as marginalization, exclusion, and even deprivation. What is surprising is that the reasons for the genitals, which deprive women of their right to participate in education, casually occurred. In other cases, socio-cultures are restricting their access to education. The factual errors on educational thoughts for woman here are explicitly used as an empirical description in this study, while its purpose is to demonstrate the shift in the treatment of female education. The result expected in this study is to reach the historical footprint of Islamic education and ensure inappropriate reasons, such as genital terms, used and abused as arguments for not allowing woman to get education.
\end{abstract}

Artikel ini mengeksplorasi peluang pendidikan pada periode awal Islam hingga abad ke-13 yang menunjukkan peran penting wan-

Corresponding author; email: 'hokohan@yahoo.co.id, ${ }^{2}$ trigodiplomat@gmail.com

ISSN 0852-7172 (p) 2461-064X (e)

(C) 2017 Walisongo: Jurnal Penelitian Sosial Keagamaan

http://journal.walisongo.ac.id/index.php/walisongo 
ita dalam pendidikan. Dapat dikatakan bahwa peran perempuan dalam pendidikan dapat ditelusuri tidak hanya di bidang pengetahuan agama tertentu tetapi juga mereka terlibat dalam patronase pendidikan dan bahkan terlibat dalam penentuan kebijakan politik pemerintah. Sayangnya, dibandingkan dengan periode berikutnya hingga pada abad ke-21, kebijakan penanganan pendidikan akbir-akhir ini berubah menjadi perlakuan tidak adil seperti marginalisasi, eksklusi, dan bahkan deprivasi. Satu hal yang mengejutkan adalah perempuan dianggap sebagai aurat dan dijadikan alasan untuk mencabut hak mereka untuk berpartisipasi dalam pendidikan terjadi begitu saja. Kasus lainnya, sosio-budaya membatasi akses perempuan untuk berpendidikan. Kesalahan faktual pada pemikiran pendidikan bagi perempuan sebagaimana tersebut, secara eksplisit digambarkan sebagai deskripsi empiris dalam penelitian ini sementara tujuan penelitian adalah untuk menunjukkan pergeseran perlakuan atas pendidikan perempuan. dengan mencapai jejak historis pendidikan Islam dan memastikan tidak tepatnya penggunaan alasan seputar aurat dan penyalahgunaannya sebagai argumen untuk tidak mengizinkan perempuan mendapatkan pendidikan.

Keywords: education; religion; socio-cultural; woman.

\section{Introduction}

Maxim "al-umm madrasah" that means a mother is precisely a woman who is considered to have an important role in educating her children confirms that education and woman are like the two sides a coin, which can't be separated from one another. In the history of Islam, it is well known that the role is played by the Prophet's wives as well as female companions in various spheres of life, especially in transmitting the Prophet's hadith, so that his name is engraved in the history of Islamic civilization. At that time, there was no classification of science as it happened in the aftermath, let alone the dichotomy of sci- 
ence then a figure may be concerned, not to mention mastering, various fields at once. For instance is Umm al-Mu'minin Aishah, the wife of the Prophet. In addition to the field of hadith, she also mastered tafsir and fiqh. Aishah took the role of explaining the special problems of women so that she would be ashamed if the problems were directly explained by the Messenger of Allah. Thus women were actively involved in the teaching and learning process, at which there was no formal education (Nizar 2008, 3)

Unlike education in the early Islam, in which its acquisition gave the same portion for both male and female as justified in prophetic sayings, the chance for women education in the present time is intentionally limited by the legality of fiqh and the stereotype reason, i.e. genital. Empirical facts of social exclusion and the deprivation of woman's rights in accessing the education demonstrate the contrast of educational acquisition for woman in the two different eras in the world of Islam.

Previous researches have asserted this finding, such as Pendidikan Perempuan (Nizar 2008), Social Exclusion, Deprivation, and Marginalization of Females of Jammu and Khasmir (Lone 2017), and Socio-Cultural Constraints of Girls' Access to Education in Mtwara District, Tanzania (Mollel and Chong 2017). Those researches focus on the same problem linked with how girl and woman are supposed to deserve their appropriate education. The problem appearing in those literary and field researches deals with singular insight on such prohibition in participating education for those females. Moreover, the influences of social culture affect the educational outcomes at certain places.

Religious constraints of women's access to education are also justified by the interpretation of the scholars against some verses of the Quran which says that men are female leaders (al-Quran, al-Nisa': 38), increasingly make women marginalized 
position. The language used in the verses of the Quran textually looks more favorable to men than to women thus raises an interpretation that does not benefit women also contributes to the marginalization of women, especially in the public domain (Nizar 2008)

This study is based on Needs Hierarchy Theory developed by Abraham Maslow which consists of five stages. Progression to higher stages of the needs occurs through motivation. Once the lower-stage need is encountered, the individual can progress to the next stage of the needs. Every individual has an ability to reach the top-stage need, and every person has an aspiration to achieve the highest-stage need, i.e. self-actualization. Unfortunately, the movement is often interrupted by the failure to encounter lower-stage needs. Life experiences, including marriage at an early age and poverty, may cause an individual to swing between stages of the hierarchy. Maslow's theory of the stages of physiological needs which include safety need, social need, esteem need, and self-actualization need is therefore applicable in this study because its emphasis and considerations are based on the provisions of low-stage need for one to achieve the higher needs. The theory is useful in illustrating the way depriving the women's needs that can affect their educational achievement. The theory is concerned with the achievement of self-actualization at the top most of the pyramid in which education may be considered to be the key to achieving it. If the girls are deprived to the low-stage need, it will impact their opportunity to participate in education, and then their self- actualization is accordingly hindered. Therefore, the community should ensure the accomplishment of low-stage needs to girls, create a supportive environment for the possibility of their education, and enable them to achieve their higher goals (Mollel and Chong 2017).

The purpose of this research is to demonstrate the shift of educational treatment toward women by reaching the traces of 
Islamic educational history and determining on how inappropriate reason such as genitals term used and abused as an argumentation to not allow girls or women to get an education. However, evidence from the previous studies has demonstrated the woman's achievement in education as they were asserted in the form of biographical dictionaries and book of collection of Muslim biographies in the early Islam. In short, the involvement of woman in education in early Islam absolutely shows the shifting fact of education for women nowadays.

\section{Women in Islamic Education History}

Islam attention toward women is not limited to how they should be treated, but it continues to their advanced education. For them, the urgency of education cannot be denied. As a religion, Islam can only be understood and lived through the process of thinking, whilst thinking activities are mostly undertaken by educated people. Thus, Islam positioned education as a compulsory to do. Whatever the sex, Islam never differentiates whether the science seeker is man or woman.

In the world of education in the early Islamic period, especially in the Prophet era, both men and women have the same right and responsibility related to knowledge. This notion can be proven from $a s b \bar{a} b$ al-nuzūl of a verse or asbāb al-wurūd of a hadith that is usually preceded by many problems proposed to Rasulullah. Women are unwilling to directly ask and present their problems to Rasulullah. Even in his explanation, the pophet's wife had a role to explain problems in relation to women that they would be ashamed if the problems are explained directly by Rasulullah. In this sense, women have involved actively in the process of teaching and learning process though there was no formal education at that time (Nizar 2008).

In the next era, there was no historical data that mentioned 
the existence of chance and condition that fully support learning process as what happened in the first period. Nevertheless, this does not mean that there is no woman figure that exists and masters knowledge in several fields. Fields with attention from women figures are such as fiqh, tafsir, hadith, and tasawuf, as well as a poem, 'ilm al-tibb (the science of medicine), calligraphy, and so forth (Nizar 2008).

It is important to know that the history of women education, especially related to the characters, is not completely covered in historical data. There are several sources that can provide historical data, among others, from biographical dictionaries. Ruth Roded, for example, in his study arranged a book of collection of 38 Muslim biographies that includes women names (Roded 1995, 19). Other studied biography books are the works of Ibn Sa'ad (230 H./845 M.). In the book of Thabagat, he mentioned 629 women of 4250 entries he arranged or only $15 \%$ of all entries he wrote. Ibn Sa'ad was one of few figures who gave more entry for women names in his collection of Muslim biographies that other writers do. Al-Khatib al-Baghdadi (463 H./1070 M.), for instance, only stated 31 women names of 7800 entries he arranged. It means that less than $1 \%$ of all number of figures is written. Meanwhile, Ibn 'Asakir (571 H./1176 M.) only stated 200 names of women in 13.500 entries he arranged. Then, Fariduddin al-Attar (628 H./1230 M.) in his popular work of Tadzkirah al-Auliyā' only stated a name out of 72 names of philosopher who are written in his book of biography, i.e. Rabi'ah al-Adawiyah (185 H.), Ibn Khalikan (681 H./1282 M.) includes 6 women figures in 826 entries that he wrote (less than 1\%). Jami (898 H./1492 M.) includes 35 women names of 564 entries he arranged. Al-Sakhawi (902 H./1497 M.) wrote 1075 women entries of 11.691 of all entries he arranged $(9 \%)$ between year of700 and $1800 \mathrm{M}$ in 
Daw al-Lämi' (Beck and Nashant 2003; Mahdi 2004). AlGhazzi (1061 H./1651 M.) only arranged 12 women names of 1647 names in his biographic collection (Nizar 2008). Recently, the scholar Mohammad Akram Nadwi, the researcher of Islamic Center of Oxford, has written 40 volumes on muhaddithät (women hadith Scholars) and found at least 8.000 names of them (Power 2007)

Around $750 \mathrm{H}$, during the Abbasiyah leadership, women are recognized for their brain and beauty (Insgrams 1983, 22). Specifically, there were famous women trained in music, dance, and poem since they were a girl. Mahbuba is one of them. The other feminist figure that should be remembered for her achievement is Tawaddud, a slave who is bought on high price by Harun al-Rasyid because of her proved cleverness by the elder ulama in astronomy, medicine, law, philosophy, music, history, Arabic grammar, literary, theology and chess (Insgrams 1983). Later, one of the outstanding feminism figures is Shuhda who was known as educated, smart and clever and became the pride of women during the $12^{\text {th }}$ century in Baghdad although the confession on women talent in Abbasiyah ended in line with the smash of Baghdad by Mongol group in $1258 \mathrm{M}$ (Nutting 1964, 196).

Women play an important role in the establishment of many Islamic educational institutions, such as Fatima al-Fihri the founder of Al Karaouine University in 859. This continued until the Ayyubid Dynasty in the $12^{\text {th }}$ and $13^{\text {th }}$ centuries when 160 mosques and madrasah were built in Damascus, 26 of which were funded by women through waqf (charitable trust) systems. Half of all kingdom customers for these institutions were also women (Lindsay 2005, 197).

Sunni scholar, Ibnu Asakirin of the $12^{\text {th }}$ century stated that there was a change for women education in Islam in the middle century; he confirmed that women can study, obtain an academ- 
ic degree and fulfill the requirement as ulama and teachers. It is particularly aimed for family that wants to ensure the probability of their children's highest education. Ibnu Asakir himself had studied under 80 different women teachers in his era (Lindsay 2005). This explains the important role of women in education, either as students or even educators.

\section{Marginalization of Women Education}

What had been outlined in education history, in fact, contradicts with what had happened in the past and in the present. The historical record that contains educational achievement of women seems to be ignored by many Islam countries. What we have today is the fact that women education often gets no attention. Cliché statement that what had been mentioned is not a generality. For women, study is not more than and only limited on attending Islamic discussion in mosque, Islamic school or other places like majlis al-ta'lim, such as women participation in majālis al-hikmah in Fatimiyah leadership as noted by many historians including Ibn al-Tuwayrand al-Musabbihī. (Virani 2007, 159)

Moreover, there were no law limitations in women education. Several people disagree with this practice, like Muhammad ibn al-Hajj (1336) who was surprised to see behavior of several women that informally follow lecture though only for a listener in their time:

"Consider what had been done by women during in gathering with shaikh for listening book discussion. At that time, women also attend to listen. Men sit in a place and women confront them. Moreover, there would be women brought into the situation, one of them would be stand up and sit and shouted. Besides, their genitals will be shown up. In her home, appearance of genitals is forbidden. How it can be allowed in mosque in front of men?" 
The term of genitals is often translated as what is impolite which is generally meant by whatever could be seen except women's face and palms. Indeed, scientific interpretation of genitals and veil always tend to be varied with more or less tight than the others (Lindsay 2005).

The ninth-century education reformation was a social (period of sweeping social), economic and political transition period resulted from hidden occurrence in different level within Ottoman emperor from Mashriq, Suriahto Maghrib, North Africa. This tendency is mostly caused by the increment of Europe presence and the spread of their secular-modernity ideas. In society level, the arrival of Christian missionary supported by Europe and American government caused the establishment of formal education system for women who had come till this period. In the beginning, private institution was taken by most Christian and rich family only. Yet, because these schools are more being accepted in social and affordable, the ideas come to middle class before finally reach poor society. Thereby, the new norm becomes more general, ideas that women must be accepted in education that she is able to realize better marriage expectation and, more importantly, to give sufficient education facilities for her children (Lattouf 2004, 62-63).

In this point, even though there are several courses to limited women, the women take this opportunity for learning and show strong will and amazing conviction. In the middle of this century, awareness and obligation toward intellectual and social awareness, especially appreciation to women suffering and struggle to participate in society, is being more real (Lattouf 2004). An important example of Western missionary contribution to increase educational opportunity for women is the work of Daniel and Abby Maria Bliss, American couple who moved to Beirut in 1866 and then built Suriah Protestant College, which 
later became American University of Beirut. In 1905, nursing program whose application was accepted by women was founded and in 1924, Faculty of Art and Science open its door for women (Lattouf 2004).

The sound of reformation occurred in Ottoman society to sultanate and finally echoed in institution level. Ottoman regime, to avoid politic and religious influence threat from Christian missionary schools and because of awareness that empire cannot expect to live without learning modern natural sciences, begin to conduct its own reformation (tanzhimāt) (Haddad 1994, 201-22). Yet, even information introduced by sultanate has no influence on emperor courses, in the 1850s and 1860s; results of reformation were reflected in daily life (Rogan 2009, 90).

The third flow can be regarded as the most important period that directs to the existence and the increment of women education in the nineteenth century and the beginning of the twentieth century because of Europe colonialism and its legacy. Short occupation of Napoleon on Egypt (1798-1801) is relatively unsuccessful. Yet, revolutionary and import ideas in technology and education prove that the power of France is more durable in Egypt and all North Africa (Rogan 2009).

Under Muhammad Ali leadership, a fan of France innovation and technology, during his governance interaction and exchange between Egypt and France in culture, academic and scientific were increased (Rogan 2009). Reformation idea of education and feminism also occurs in other places of Arab world. Syrian scholar Butrus al-Bustani (1819-1883) was included as the first figure who was advocating women education rights in 1847 (Ashour, Ghazoul, and Reda-Mekdashi 2008, 6).

The next two decades in Tunisia, reformist Ahmed Kheireddine emphasized the importance of women education in per- 
forming household and children nursery (Youssef 2005, 55). It is small but important step in women emancipation within society. Advanced in Egypt, after British took over France in Egypt civilization mission they also give contribution for education reformation for women education. In his work entitled, Modern Egypt, Lord Cromer who was occupied almost three years as High Commissioner of Egypt wrote, "By limiting the scope of women interest to very limited world, the sick of intellectuality and the wizened of mental development occurs in one and a half of Muslim countries population" (Cromer 1908, 124).

In 1924, when the Faculty of Arts and Sciences at the American University of Beirut began accepting applications from women (Lattouf 2004), the norm that knowledge is not ignorance defending women's dignity and morality (Totah 2002, 78) had been implemented. In facing detention and excision from formal education, as well as informal learning in literary or learning scope in their family (Lattouf 2004). Besides, women like Mayy Ziyadah and Mary 'Ajami went to continue higher education in Europe and back to found famous review and give unlimited contribution to literary, printed and production scope in Arab world.

Unsupported education for women is not ceased in line with the development of the world of education, especially in Islam-based countries. In a statement in 2013, Organization of Islamic Cooperation noted that Islamic countries limit education opportunity for women (Gokcen 2013). UNICEF noted that from 24 countries, the number of women participation is less than $60 \%, 17$ of which is Islam countries; more than half of adult population is illiterate in many Islam countries, and the proportion reachs $70 \%$ within Muslim women (OIC, ISESCO, and UNICEF 2005). The other ulama claim that Islam countries have gender gap in highest education (Donno and Russett 2004, 
582-607). In 2012 World Economic Forum, a study on gender gap finds that 17 of 18 countries have worst performance from total of 135 countries, it is the member of Organization of Islamic Cooperation: Algeria, Jordan, Lebanon, Turkey, Oman, Egypt, Iran, Mali, Morocco, Côte d'Ivoire, Saudi Arabia, Syria, Ched, Pakistan and Yemen (WEF 2013).

This worst fact should be a reference for the important review of education for women. It is recalling that Islamic education history is never apart from the participation of women figures. The role of women in education can be traced not only in certain religious sciences but also they took apart in educational patronage and got involved in political policy.

It needs to be recognized that history of women education in Islam is actually inspired by the Prophet wife, Khadijah. Meanwhile, the role of Aishah and Hafsah who are also his wives explained the same things. The questions are why women education shifted; it is initially prioritized but is gradually ignored later, whereas it is clearly mentioned in a hadith how the prophet Muhammad saw. praised Madinah women more because of their curiosity on religious knowledge (Lindsay 2005). Then, it is also important to know why those who understand religion (fuqah $\vec{a}^{\text {') }}$ try to be hypocrite on women education because of innate character problem and genitals.

If compared to women education listed in historical data, women involvement in education in Islamic countries doesn't seem as phenomenal as women education achievement in the past. The views on prioritization of men in having the education that is higher than women indicate that there is specialty. The existence of privileges that may be the result of aware knowledge or from social pattern that makes the correlation between Islamic scholar, men and women, is more problematic. In line with what is stated by Laila that conservation of Sassan Persia 
tradition in Abbasiyah society creates limited situation for women movement (Nizar 2008).

Family bound also has influence on women education, especially on the history of the women. Blood relation makes women have opportunity for learning. According to al-Sakhawi, as restudied and re-explained by Ruth Roded, $20 \%$ of women learn from male teachers that are the family member, $15 \%$ of them study from female teachers who also have family relation. On the other part, it is mentioned that $35 \%$ of women learning only from male teachers that is their family, and there is $88 \%$ of women educated especially by their own family (Nizar 2008).

The percentages above explained the limitation of educational achievement for women that is not as free as men. The limitation on having education goes on in line with the opinion of unusual education for women that is limited by sexism problem in women.

Without mentioning interpretation of ulama toward verses in al-Quran which said that men are women leaders (al-Quran, al-Nisa': 38), the message can make women in a more marginalized position. The language used in al-Quran gives more support to men than women, and thus giving rise to a disadvantageous interpretation for women, especially in educational scope (Nizar 2008).

Women marginalization in Islamic history existed because of two things. First, tribalism spirit of Arab that grew up again after the prophet passed away. Second, the comprehension of religious tenet related to women is far from its historical correlation. Fatimah Mernissi strongly regarded that backwardness of Islam women is historical deviation conducted by Islam masters after the Prophet passed away (Mernisi 1991, chap. 2 and 3).

The economic problem also becomes the factor of why women education is only limited to middle and high classes. To ob- 
tain education with specific mastery, it needed high price to have long journey to several areas that are regarded as the center of knowledge. Having study to many shaikhs also needed much financial support. It is harder because there is fiqh understanding that obligates women to be accompanied by her mubrim when they go everywhere which is, of course, adding the educational fee itself (Nizar 2008).

The problem of access to educational opportunities in Tanzania, for instance, has remained as a big problem among girls. The statistics indicate that the number of girls who complete different levels of education is deficient. In the post-primary level, girls' participation in education is significantly lower than that of boys. Similar data show that girls' enrolment in Technical and Vocational Education and Training is still low for girls, whereby boy students accounted for 55 percent of learners in 2008. The situation is essentially bad at the higher education level; girls' enrolment has barely reached 34 percent (UNESCO 2011). The percentage of girls completing a full secondary education was extremely low $0.8 \%$ in 2010 . Nearly 1.2 million teenage girls are out of school. Repetition and drop out proportion are significantly higher to girls while completion rate is very low; also there is a strong gender inequality in providing education and performance in education between girls and boys (Mollel and Chong 2017).

Socio-cultural constraints of women's access to education show the effect of their participation in education. Early marriage, male preference, social perception and social roles are among the key socio-cultural factors hindering woman education. In this case, the government and other education stakeholders should sensitize the community on the need and significance of women's education for themselves and the community in general. Education stakeholders should also launch mass me- 
dia programs like television and radio programs to educate and discourage the bad socio-cultural practices in the community that deteriorate girls' education (Mollel and Chong 2017).

\section{Conclusion}

Education and women are two inseparable things. Adagium that asserts the significant role of mother as an educator at the same time shows the woman's right and responsibility to the education. The involvement of the Prophet wives either as students and model of educators in transmitting the prophetic teachings confirms the truth of their important role. Unlike women education in the beginning of Islamic era, especially in the Prophet era when the same opportunity of education between women and men is facilitated and obtains justification from the Prophet, in the end of the golden era of Islam until nowadays, the opportunity of women education is more limited and intentionally limited by fiqh or sharia legality, which is very dominant in Islamic education institutions. Meanwhile, fiqh understanding that obligates women to be accompanied by her mubrim when they go aboard for educational purposes, at that time and in the present, is still practiced until the present time. This makes women movement in obtaining education restricted. In addition, socio-cultural factors, such as early marriage, male preference, social role, social perception, community's attitude towards women's education, affect the educational outcomes, such as the dropout from school, poor academic performance, inequality, and limited time to study.

\section{Bibliography}

Ashour, Radwa, Ferial Ghazoul, and Hasna Reda-Mekdashi, eds. 2008. Arab Women Writers: A Critical Reference Guide. Cairo: American University: Cairo Press. 
Beck, Lois, and Guity Nashant, eds. 2003. Women in Iran from the Rise of Islam to 1800. Women in Iran from the Rise of Islam to 1800. Illinois: University of Illinois Press.

Cromer, Evelyn Barin. 1908. Modern Egypt. New York: MacMillan.

Donno and Russett. 2004. "Islam, Authoritarianism, and Female Empowerment." World Politics 56 (4).

Gokcen, Ufuk. 2013. "Hope and Despair for Women in Islamic States.” Jeddah: Organization of Islamic Cooperation.

Haddad, Mahmoud. 1994. "The Rise of Arab Nationalism Reconsidered." International Journal of Middle East Studies $26(2)$.

Insgrams, Doreen. 1983. The Awakened: Women in Iraq. London: Third World Centre for Research and Publishing Ltd.

Lattouf, Mirna. 2004. Women, Education, And Socialization In Modern Lebanon: 19th And 20th Centuries Social History. Lanham, Maryland: University Press of America.

Lindsay, James E. 2005. Daily Life in the Medieval Islamic. Connecticut: Greenwood Publishing.

Lone, Adil majeed. 2017. "Social Exclusion, Deprivation, and Marginalization of Females of Jammu and Khasmir." IJRDO Journal of Educational Research 2 (2): 31-41.

Mahdi, Ali Akbar. 2004. "The Iranian Women's Movement: A Century Long Struggle." The Muslim World 94 (4). Wiley Blackwell: 427-48. doi:10.1111/j.14781913.2004.00067.x.

Mernisi, Fatimah. 1991. Women and Islam. Oxford: Basil Balckwell.

Mollel, Neema Silas, and Ren Chong. 2017. "Socio-Cultural Constraints of Girls' Access to Education in Mtwara District, Tanzania." Khazar Journal of Humanities and 
Social Sciences 20 (3): 108-25. doi:10.5782/22232621.2017.20.3.108.

Nizar, Samsul. 2008. "Pendidikan Perempuan: Kajian Sejarah Yang Terabaikan.” Lentera Pendidikan 11 (1): 1-18.

Nutting, Anthony. 1964. The Arabs. New York: TBS The Book Service Ltd.

OIC, ISESCO, and UNICEF. 2005. "Investing in the Children of the Islamic World.” New York: Organization of the Islamic Conference (OIC), Islamic Educational Scientific and Cultural Organization (ISESCO), and UNICEF.

Power, Carla. 2007. "Reconsideration: A Secret History." The New York Times Magazine, February.

Roded, Ruth. 1995. Kembang Peradaban. Mizan. Bandung: Mizan.

Rogan, Eugene L. 2009. "The Egyptian Empire of Muhammad 'Ali." In The Arabs : A History. London: Allen Lane.

Totah, Khalil A. 2002. The Contribution of the Arabs to Education. New York: Gorgias Press.

Virani, Shafique N. 2007. The Ismailis in the Middle Ages: A History of Survival, A Search for Salvation. Oxford: Oxford University Press.

WEF. 2013. “The Global Gender Gap Report 2012.” Switzerland: World Economic Forum.

Youssef, Zayzafoon Lamia Ben. 2005. The Production of the Muslim Woman: Negotiating Text, History and Ideology. Maryland: Lexington Books. 
This page intentionally left blank 